\title{
"GLOCAL" GOVERNANCE CAPACITY: MINING HERITAGE OF SARDINIA
}

\author{
A B S S T R A C
}

The paper explores government capacities of Sardinian mining heritage (dating back 8 thousand years of mining culture, crashed as an industrial engine in ' $60 \mathrm{~s}$ and proclaimed as heritage of great importance by UNESCO in 1997.). Nowadays, characterized by depopulation, lack of management and managing, astonishing sites are conceived, semi-perceived and pseudo-lived. The research has an orientation, character and strategy, pragmatic orientated with qualitative character; oriented to determine what and how should be done in relation to what is wanted to be done. It is a multidisciplinary approach, whch implies that research always takes place in a specific social, historical, economic and political context. Questioning trends and urban potentials of Sardinian territories, with a contemporary European strategy, the research discusses on shared cultural experience as long term sustainability, lies down and raises at the level of the local community. The main paper issue is examining "Glocal" - local and global intergovernance capacity by using "Axes of partnership" (local Parco Geominerario Storico e Ambientale - European and Global Geoparks Network - UNESCO) as the first component of creative partnering, which leads to integration of local communities into participative, cultural, redevelopment process in the context of Sardinian mining heritage as system design sustainability.

Nađa Beretić

KEY WORDS

University of Sassari - DADU in Alghero

GOVERNMENT

Arnaldo Bibo Cecchini

GOVERNANCE

University of Sassari - DADU in Alghero

LOCAL COMMUNITY

Zoran Đukanović

MINING HERITAGE

Alessandro Plaisant

SARDINIA

University of Sassari - DADU in Alghero 


\section{TRENDS AND POTENTIALS OF SARDINIAN TERRITORIES}

The city was like an image until half of XX century, after cities and their stories became inseparable: "urban space and narrative space". After World War II, cities have left its limits existed (centralism or dispersion) and asked for new forms to represent it. In Sardinian cities (Italian generally) the theory of "territoriality" became in focus. The theory is landscape-oriented and emphasizes the emergence of new relation about interdependency between the local and the territory. The environment dimensions make a constituent element of contemporary life. Relations indicate invisibility of the biological and cultural dimensions of spatial life and progressively favour structural economies oriented towards an environmental direction.

The dispersion process of the Sardinian cities and territories is understood as processes of spatial transformation devoid of urban quality, identity. Against settlements designed for tourists to the last detail, it is sometimes pushed up to allow users to live a fiction out of context and timeless, at hyper cultural and hyper gesticulated villages, the remaining mass appears sloppy, random, anonymous, and degraded. Often the landscapes of the holiday become a projection of desires, in a sense a statue, a masking of the real conditions of urban life, which is quite a mere invention of dreams. Some other times, the landscape turns to "brand-scape" ${ }^{2}$ when techniques are marketing-oriented to guide the design of the spaces for tourism, in order to increase the value perceived by the user. Even if tourism mostly lasts for a season, it is shading life of the local habitants while experiencing the cities for a full 12 months yearly. But, it is maybe not 'just' tourism-caused. Communication code has changed within the relationship system while the concept of limit is losing its meaning. Those new relations produced modification in public-private relations, too, and "the cyberspace replaced the traditional meeting places, radically modifying the socializing mechanisms"3. Discussing on present recognition and fabrics of cities we can point out omnipresent changes and temporality. From a sociocultural aspect, we have those attributes in the everyday life of the habitants and visitors. New models of living and the tourism fluctuations, as strong industry, characterize Sardinian territories. They are shaking the limits of belonging, perceiving, evaluating and the subject we are projecting to and with.

Enhancing the Sardinian cities is dealing with issues of leisure as the social dimension of the city and it is a general critic on mass tourism. Leisure is understood as intermediate space or frontier between tensions, it may take on the form and function of a neutral zone, where reciprocal identities may be attested, remaining separate but each beginning to possess experience of the other. The 
different ways of seeing the world and the various styles of thought are defined, ultimately, are the basic elements of a collective consciousness of the city. Urban branding should be promoted trough urban strategies linked with leisure and culture-based economies. In today's societies, the role of the voluntary sector emerges as an instrument of leisure management policy. The local community should not "just" give a support, rather to act as initiator as well. ${ }^{4}$

At the European Union (EU) level, there is legislative still to be tested, if the coastal tourist settlements through the application of the international principles can base the foundations for sustainable growth. Coastal areas are the most attractive to be the first target. Regarding some of the documents still to be verified are: European Landscape Convention - CEP, 2000 European Charter for Sustainable Tourism - CETS, the 2003 Convention on the protection of the cultural and natural heritage of the United Nations Educational, Scientific and Cultural Organization (UNESCO) Convention on the Protection of the Cultural Submarine Heritage of UNESCO, etc. The questions to be tested address the redevelopment, enhancement and satisfy, in accordance with local authorities and tour operators, tourism demand without compromising both the quality and natural heritage sites, which are important resources of these areas and attractions for tourists, both economic and social interests of the resident population.

In order to initiate the process, it is important to understand its meaning for the all stakeholders (local to regional, then visitors), as a quality of life for the community at first - to recognize it. It does not exclude the development of tourism potentials; rather, the focus is primarily on local communities to start and ensure culture-led regeneration and shared cultural experience as longterm sustainability. Recognized as a qualitative potential, while redeveloping it on holistic base and oriented to sustainable system design, human resources, as the biggest value of cities and its territories, should be included in the participation process. Speaking about the effective implementation or not, it is not true that some intentions don't exist at all, but if they do, they are mainly sporadic or incomplete. Building up local capacities not only contributes, but bases investment in territorial sustainability.

Driving by nature and culture, both oriented to long-lasting socio-cultural, economic and environmental sustainability, innovative government strategy should ensure dialogic relationship at local, territorial, Regional, European and global levels. This, "Glocal" (local and global) dimension is the main cultural opportunity of mining heritage in Sardinia. Its governance capacity, to integrate local communities in participative, cultural, redevelopment process is the task of the main research issue. 


\section{MINING LANDSCAPES IN SARDINIA}

Sardinia is an island in the Tyrrhenian see characterized by more than 8 thousand years of mining history and ancient culture. Most of mining facilities are located in coastal landscapes. The mining activity has modelled the landscape ever since, but the vivacious smell of ancient history and culture among the wonderful marks of mining industry in contact with the astonishing nature has still remained. After the mines closed during the 1960s, particularly mining landscapes and its character became recognized as a heritage of outstanding importance on the national and international level during the 1990s.

For the purpose to protect its future development as precious cultural heritage. UNESCO has been declared Geo-Mineral Park of Sardinia as the first Geomineral, Historical and Environmental Park of Europe under the name Parco Geominerario Storico e Ambientale. It is a prime example of the new global network of Geo-site - Geo-Parks, established during the Conference General of UNESCO (Paris, October 24, 12 November 1997). The UNESCO included it in the list of Cultural Heritage Sites, where Industrial Heritage is a subcategory of "mining landscapes" or "mining regions" as a whole, not only buildings or infrastructure. The official statement of recognition was signed in Paris on the $30^{\text {th }}$ of July 1998 and has been formalized with the document "Carta di Cagliari" during a special ceremony (Cagliari, 30 September 1998) to present the highest authorities of the Italian government and UNESCO (42 members of Europe are at total network of UNESCO's care of Geo-parks), as well as the promoters of the park: the Autonomous Region of Sardinia, Sardinian Mining Authority (EMSA), the University of Cagliari and the University of Sassari. "Carta di Cagliari" made in order to acknowledge the international values of the "Geological, Mining, Historic and Environment Park of Sardinia". Municipalities and communities took a part at was 81 (of 376 total of Sardinia). Total area of the heterogeneous Regional Park includes 60 mines on 3770 square $\mathrm{km}^{5}$.

Institutionalization of it was concentrating to care about main areas by recognizing vulnerable patrimony fields: archaeological (injured by mining works), techno-industrial (state of neglected and lack of museum structures), real estate (lack of restoration interventions and present condition of dangerously dilapidation), cultural (good documentation, photography, books and etc. are not adequately conserve, results destruction and lost), ecology and environmental (phenomenon of pollution, documents and assumption are seriously alarming). The project and its actions are dedicated to the scientific view and tourists to research and represent incredible marks of this heritage resource from more than 8 thousand years of mining culture. The Park is aiming its objectives and 
activities in recognition of the universal value of the mining areas of Sardinia by UNESCO. At the same time, planning and management of the Park are directed to carry on planning community at a regional and national level with the constant collaboration of and with UNESCO but are particularly useful and indispensable for the success of the Project.

Steps of the formalization process of the mining landscapes in Sardinia (after the failure of mining industry in the 60s) are adopted of Pinna $2008^{6}$.

- 1970s and 1980s - Crisis of the private mining sector and intervention of public sector on State and Regional level.

- 1980s and 1990s - Divestiture and consequences of mining areas.

- 1990s - Manifestation of interests for mining sites and its conversion from public sector. Adoption of the laws was 221/1990 and 204/1993. Activation of lively cultural debate and birth of administrative authority: Association on Parco Geominerario, Storico e Ambientale for SulcisIglesiente (point on needs for patrimony of historical, cultural and archaeological-industrial valorisation of mining sites). Interventions were financed by the State and Regional budget and, maintained by: EMSA (Sardinian Mining Agency), Community and supervised by BAAAS Sardinia. Two main phases that were determined are: predisposed for UNESCO's file correspondence and feasibility study of technical, economical and legal aspects.

- 1997 - New global network of Geosite-Geoparks established during the General Conference of UNESCO (Paris, October and November) with scope to valorize technical, cultural and ambient patrimony of mining areas. It was founded and established by the Environmental Ministry of Region of Sardinia (December).

- 1998 - Recognition of Parco Geominerario, Storico e Ambientale della Sardegna in UNESCO's global network of Geosite-Geoparks. "Carta di Cagliari" with its leading principles is recognized by UNESCO, National Government, Region, Municipalities of Sardinia, EMSA and University of Cagliari.

- 2000 - Efforts and movements in terms of law base made by Councillors, leaded by Giampiero Pinna: institutional recognition and approval of Senate with determination of related financing.

- 2001 - Founding decree was written by Environmental Minister Borodon in April and Minister of Industry for trade and crafts in May. The agreement is also signed by President of Region of Sardinia in July about providing 486 jobs for socially useful work on issue with adequate financial support every phase (e.g. 63.8 billion of budget for 
Plan of recovery and rehabilitation for Sulcis - Iglesiente - Giuspinese mining area). Decree about internal norms was finally established by Environmental Ministry, in October.

- 2015 - Governing structure is not stable yet.

Those former mining sites have been the development engine of Sardinia from the ancient times. Nowadays (less than 20 years after the proclamation of Parco geominerario), they are "the most depressive area in Europe", according to an interview with commissary of the administrative body. They are without local economy and almost depopulated - without life. The foundations for sustainable redevelopment of mining coastal landscapes recalls indeed an eminently space of imminent public. The foundation of the theory of space production by Henry Lefebvre (1991), define space as a place always conceived, perceived and lived, while the present mining coastal landscapes in Sardinia are characterized as conceived, semi-perceived and pseudo-lived. Thus, the redevelopment demands those cultural heritage sites to be presented as qualities of landscape, which attract both, economic and social interest, the primary of its local communities - the place of people. People relate emotionally to their physical environment and environments affect their behaviour and social activities while perceiving, conceiving, living and evaluating the place. Always considering user preferences (socio-cultural issues) and environmental need, it asks an innovative governance model includes the community.

The first set of the topic specificities embraces the redevelopment of heritage sites is protected and international. All the types of heritage protected by UNESCO have some guidelines to follow in common. Some of them are: "to exhibit an important interchange of human values, over a span of time or within a cultural area of the world on developments in architecture or technology, monumental arts, town-planning or landscape design" ... "to bear a unique or at least exceptional testimony to a cultural tradition or to a civilization which is living or which has disappeared" ... " to be an outstanding example of a type of building, architectural or technological ensemble or landscape which illustrates significant stage(s) in human history" (UNESCO criteria ${ }^{7}$ ). Those guidelines indicate that the way of the representation within redeveloping process is enormously important, much more than it is the task of any work in the architectural fields (urban design, landscape architecture, architecture and etc.).

The second particularity, present potential, as well as a treat is the concept of tourism. Partly, it relates to the context of Sardinia as a wide recognized island with astonishing landscapes, seascapes even more, which are moreover wished destination. From the other hand, concept of tourism is inevitable issue related 
to any heritage sites. Addressed to escape, as an outcome crowding-out of the local population appeared a syntagma "sustainable tourism". That relation determines the quality of tourism is constituted of two main concepts: benefits and costs. Benefits include new jobs, the image of the place, its networking with other places resulting in a development of trade and commerce, and costs are operational costs, investments, emergence of negative externalities such as pollution, congestion, wear and tear.

Redevelopment processes of mining heritage seascapes should deal with: temporality of constant changes in socio-cultural structure (as well as natural and spatial attributes) and the representation of place authenticity. Aimed to prevent a phenomenon of non-spaces, the redevelopment mechanisms should be based on local, culture-based, economy considering 'sustainable tourism'.

While perceiving, conceiving, living and evaluating the place people relates emotionally to their physical environment and environments affect their behaviour and activities. This could be a definition of intensity from a more landscape aspect (ex-mining landscapes). It is searching to define the urban (ex-mining settlements), as all-important quality "that is an identity-defining intensity" Radović9; without an easy identifiable and measurable aspect, then 'the level of complexity'. Examining the concept of liveable-lovable place, we are dealing with perceptions and aesthetic attributes of landscape and its crucial dichotomy of material-immaterial. The individual cannot be separated from the environment, he is a part of the system he perceives, and thus the strategies he chooses to become the environment, he in turn experiences as being external to himself ${ }^{10}$. We can say that created intensities from identity are pretty subjective category (but in relation to the others) which constitutes the concept: liveable-lovable place. "The meaning of place is grounded in existential or lived consciousness of $i^{11^{11}}$ " and so its limits are found in the limits of human consciousness. As the intellection of place, as diffuse and differentiated range of identities and significances, it is a context of human experience, constructed in movement, memory, encounter and association. Not speaking "just about" intensity of emotional response, according to the writings of Henri Lefebvre "the city as oeuvre"12, he is referring to the city as a work of art (artwork) and urban space as a creative product and context for the everyday life routines of its inhabitants. With the invaluable impact, he celebrates community, highlights past memories and increases the economic impact of a city as a unique contributor to a quality urban living environment. In such a manner, intensification of ordinary life is based on proudness and built on local economies ${ }^{13}$. Thus, the revival process of Sardinian mining landscapes recalls local community to be included in its own life and love - to participate in its governance process. 


\section{GOVERNANCE CAPACITY}

The redevelopment process of the mining heritage seascapes in Sardinia should contribute to aesthetics, socialization and the economy at the same time, as a long term sustainability of liveable-lovable place and system design. The new development strategy should enrich and celebrate the culture and rejuvenates the sense of place, the place for people (nowadays missing). Challenges of innovative governing should meet depopulation of ex-mining settlements, management and managing as the biggest lack recognized (18 years after the official declaration of the Geo-mining park of Sardinia).

Rethinking the organization of the elements of the mining landscapes means to propose a logic of territorial equality, through focused interventions at the different scales (from local to regional), by which specific situations take on the value of urban centrality, while others rediscover the natural generative values, designing a territorial matrix of strategic places and opening up favourable opportunities for the involvement of the internal territories for their contiguity with the nodes of the matrix. Connecting the small hamlets and rural residential areas to urban structures, services and supporting facilities, can help to enhance the public and representative use of the ex-mining sites, environmental restoration and safety, recovery and innovative reuse for some monumental structures and pathways related to the past of the places. Far away from the idea of object-oriented museum culture, a spatial perspective to access the mining culture as a genuine process of cultural production through the transformation of information into the knowledge is borrowing some of the typical processes of the "contemporary library world", intended as a service on global and local level simultaneously, a "Glocal" system. Extremely dynamic and vital, actively projected towards its users and the territory, adjusting and redefining itself are overall environment change culture-led governance should meet. As such, this territorial system must reorganize and manage its components: the structural aspects, its institutional purposes and the rules governing the action, its documentary collections, the expertise, the new technologies (and the resulting digital divide) and the used equipment, the financial resources, and so on.

Environmental reserves are a key role for growth, competitiveness and employment and those set out the actions necessary for the implementation of sustainable governing. Three priorities to focus on are highlighted, according to "Europe 2020" (EU's growth strategy of European Commission, to deliver high levels of employment, productivity and social cohesion), and those are: "Smart growth - developing an economy based on knowledge and innovation; Sustainable growth - promoting a more resource efficient, greener and more 
competitive; Inclusive growth - fostering a high-employment that promotes economic, social and territorial cohesion. ${ }^{14 "}$ Europe 2020 is the strategy for the coming decade.

Conductive to better understanding of the condition and potentials, the research was also organized practically. It bases results (in addition to the study of research) on interviews and questionnaires done. The first step was determination samples of respondents. But, they are not just respondents, they are participants. Public participation and collaboration are necessity of sustainable city ${ }^{15}$. This capacity is missing in the governance with Sardinian mining heritage. It is necessary to build it up, but at first there is a lack of understanding of its significance at the governing level. There are two main issues to be strengthened up.

Firstly, if the participation exists, it is not full; it does not include all levels of participating (informing, consulting and making decisions) or institutionalization. The benefits of using participative methods should achieve are dual. Local community akin it: involves two-way information, contributes to active citizenship, affect the development of skills on social awareness, and contributes to establishing new relationships and relocation of power and resources in the management of local and urban development. Stakeholder involvement related to it is focused on decision-making and implementation plan, allows identification of interests and influences, gives an opportunity for resolution of conflicts in a timely manner, contributes to a more realistic and effective planning.

Secondly, the planning is missing. Interdisciplinary projects mainly exist, but, usually without planners. The contemporary role of planers could be useful to strengthen future efforts in the process. Whichever technique we chose to place for space development, we must always count on: uncertain management through systematic project planning, dynamic work strategies in real time measurement technologies for its habitants. Planning and planer's knowledge about know-how and communications techniques are missing link to be reached. Different from other specialized expert planers, it must be able to meet the common interest of all; it must be able to plan "in the face of conflicts" ${ }^{16}$ meeting the interests of scientific and artistic fields, too (e.g. as economic prosperity as faith, hope and love of habitats).

About the structure of stakeholders, in relation to the interviews and questionnaires was comprised for all sectors: public, private and civil. Stakeholder group is different from an educational background, executive power, and, also, current and past experience; but all of them (also the ones 
who retired or changed position) are still strongly engaged on issues about Parco Geominerario, Storico e Ambientale, and believe in its future. They are mainly from Sulcis-Iglesiente-Guspienese, the biggest and most powerful area ever since. To present variety, stakeholders who participated are: ex-President of Province Carbonia-Iglesias, ex-Major of Carbonia, Member of Italian Parliament, Senate of the Republic, Member of Italian Parliament, Chamber of Deputies, Dean at Faculty of Architecture University of Cagliari, ex-Director at Geo-Mining Park of Sardinia, ex-Director of Mines Iglesias-Iglesias, President of Association Pozzo Sella for Parco Geominerario (2001- 2009), Member of Governing Council of Consortium for Parco Geominerario Environment History of Sardinia, Current Commissar of Parco Geominerario Agency from December 2013, Current director of Pozzo Sella - Association responsible for Geo-Mining Park of Sardinia Region, Owners of mine, Young researcher on mining issues, and the most important: Retired miners (have been working for 30 years in different mine places) and active participants in the process of revival, engaged as guides in mining sites.

Leaded by the two main objective participants, answers structured by categories were given: people oriented objectives (wider social issues) and creating place oriented. Each of them had 4 subtopics with multiple choice selections to choose. There was no number limit in choosing options, because of the three main assumptions. Firstly, the stakeholders and their opinion still are not recognised in the full capacity - by being included in the process about issues of Geo-mining landscapes of Sardinia "without limits", they are free to express it more and more particular itself. It also strengthens trust-building and sense of belonging to, contributing to, having meaning in something's life (it is component of spiritual wellbeing and pride of belonging to the issues). Secondly, the larger is list, they will be better informed (if they are not familiar with some fields) and consulted (as a first steps of participation process). Thirdly, without general strategy on Regional level, stakeholders are not able to focus on objectives or let alone that they have hierarchical categorisation of priorities - so putting all opinions together is possible pre-step for networking and joined visioning (from local to Regional level). Likewise, based on the assumption's facts, the research goal was directed towards building up larger list of different interests and issues stakeholders recognized as problems or potentials or they are "just" interested in to participate.

General conclusions obtained about social issues showed interest of stakeholders in: a) Preserving valued cultures and exploiting opportunities for new forms of cultural development: preserving existing cultures, e.g. industrial heritage, landscape; highlighting high quality existing features with 
complementary high quality, new design; promoting inter-generational respect and understanding; b) Preserving valued cultures and exploiting opportunities for new forms of cultural development: Up-skilling local people for better employment opportunities; c) Ensuring employment opportunities appropriate for the development: creation of innovative job opportunities; new or adapt old physical infrastructure for new enterprise and jobs; d) Ensuring social equity in the mining landscape development: providing affordable access to services; involvement of local community in design of building. Development objectives important from stakeholder's viewoint that are place-oriented are: a) Improvinh perceptions and image of the mining landscape development: promoting sense of identity through local events; overcoming lack of the confidence for the (financial and social) investment in an area; b) Contributing to strategic sustainable objectives in the urban context: ensuring an appropriate mix of uses on the mining landscape site; c) ensuring physical accessibility: overcoming physical barriers such as abandoned industrial railway tracks etc.; providing for walking, cycling, public transport; d) Providing liveable-lovable and sustainable local communities: providing high-quality housing and public realm. Human resources are the most valuable at all.

The following subsections represent possible governance models, according to the existing and potential governing capacities.

\section{Inter-government Partnership}

Turning to the initial steps Sardinian mining landscapes are missing (the placebased redevelopment process and cultural revitalization), the inter-government partnership could be a cultural planning model for long term sustainability, for acting "Glocal". This model is mostly absent in the Sardinian context.

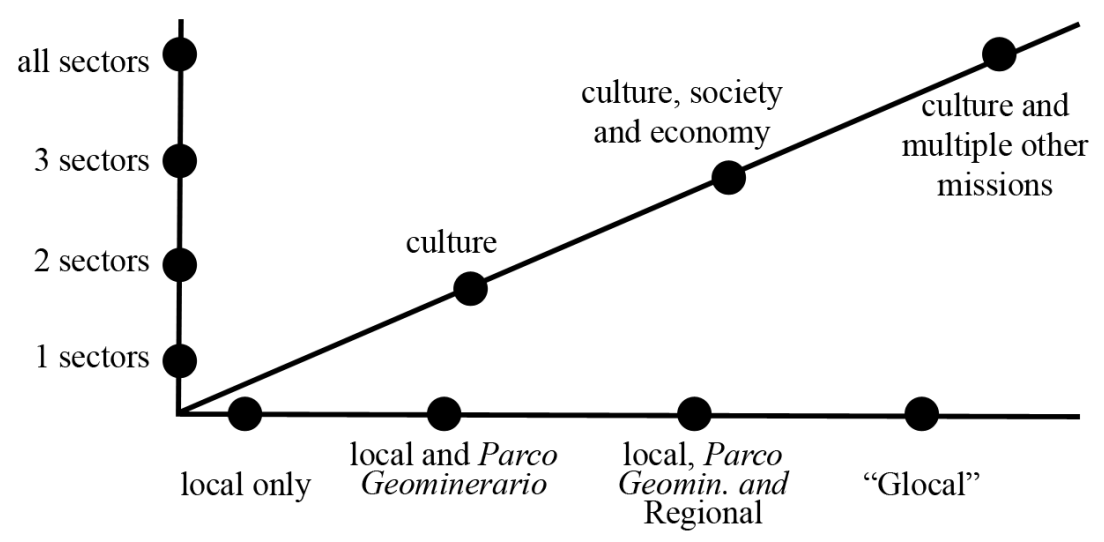


The diagram (Figure 1) explains inter-government partnership benefits in relation between sectors and stakeholders. The model is adopted in the Sardinian context of mining landscapes according to the 'Axes of partnership', components of creative partnering ${ }^{17}$.

By using this model, the possible benefits to gain are: a) a community event - enjoyment of the cultural community; b) general aesthetic and "drama" of the site - demonstrates a commitment to a particular place and its distinctive qualities; c) designing on distinctiveness - recognition and hierarchy of public places; d) mobilizing the will of public - redevelopment process needs significant input of time, talent, visioning and financial commitment on the part of the arts community and public sector support (collaborating initiators and creating partnerships); e) money for stakeholders and the site; f) crossboundaries support and funds from other functional agencies and levels of government; and many other.

Maybe Parco Geominerario Storico e Ambientale lives “just in paper", but it has enormous potential capacity. Seducing cultural and natural shining compression occupies no small area of the Sardinia Island. It is conceived at global level (proclaimed by UNESCO and first of Geoparks European Network). But, to construct and live "Glocal" dimension as a development engine, it is missing local dimension in all. Existing strategic key have been always oriented topdown: administrative and legal basis was created 18 years ago (there are still particularities about ownership rights and executive power to be resolved, but the basis for acting exists), association Pozzo Sella regional authority for managing funds in the same period, the fund is not a problem. But, what about bottom-up strategic key? It doesn't exist. Even if the public is present during some rare projects, it does not fully participate and it is like a partial experiment more than the strategic key. Top-down and bottom-up must be parallely processed, as one strategic key. To start a bottom-up, local community must be given know-how. Starting with small (local) steps, strengths of small intensities can create a dense stamp of the big vision (regional and more). Local identity and proudness of the few ex-miners left is still "burning fire" (from the results of the interviews) and existing capacity to start with, to start now while they are still alive and able to transmit the character of mining culture. Only working parallely and starting from giving know-how to local community, we can anticipate planning for a sustainable future (although somewhat uncertain as every future is) or at the other hand, leave depression that blurs existing (Figure 2). 


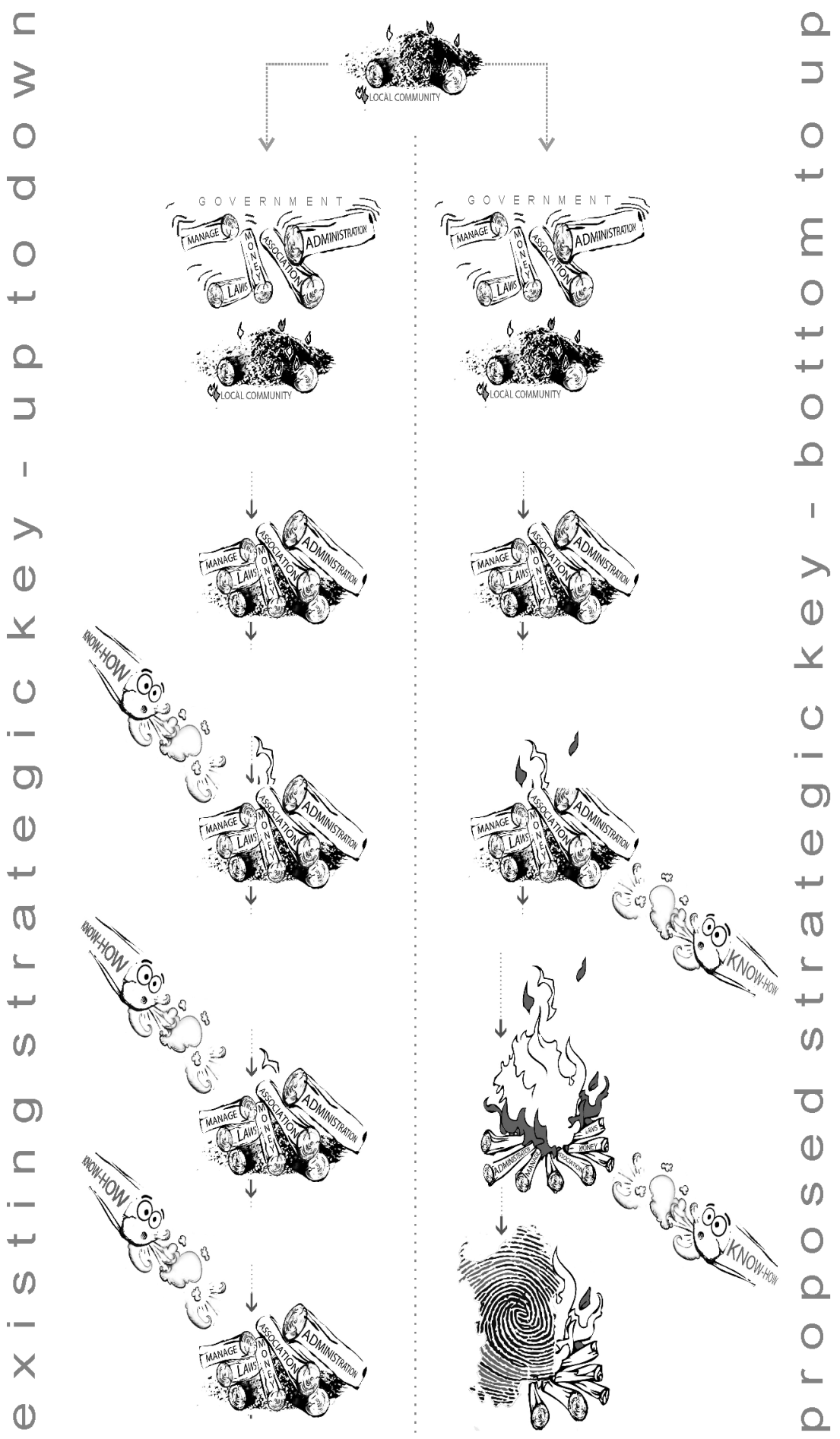

Figure 2. Know-how for local communities is the first step to upgrade existing governance process of Sardinian mining heritage. Top-down and bottom-up strategic keys must be parallel processed for sustainable development. 
Researching feasibility of the governance model, besides the conceptualisation of benefits themselves, it is necessary to highlight their operationalization through policy implementation, from the perspectives of different actors involved. This is absolutely missing chain to be set up and it is important to point it out, but it is not question the paper explores.

\section{Possible Governance Structure of Mining Landscapes in Sardinia}

Culture-led redevelopment governance strategy has a comprehensive concept construction, where the role of planer is focused on: a) common knowledge (to know together) - information, consolidating, mapping and sharing; b) common ground (where there are information gaps and agreement) - identifying information gaps and shared opportunities; c) community capacity (where do you want to be and how do you get there) - mapping the cultural context and developing a strategic action plan. The governance process should produce a common vision and objectives, opportunities for integrated programs and projects, and opportunities for widening partnership resources. By maximising the overlaps between stakeholders, the product is more successful. ${ }^{18}$

Concept fundamentals for the context of the Sardinian mining heritage are in the process of resolving conflicts and pursuing shared interests bases and those rise on giving know-how to local communities, contributing to building up the local economy and culture production of memory, history and culture, about innovation as unique, rare and specific place for its habitants (and tourist in addition). Figure 3 presents parallel existence and one of possible organisational models for the potential governance capacities of inter-government partnership for the Parco Geominerario, Storico e Ambientale della Sardegna. Presented inter-government partnership model is considered a base to start with for any functioning of the authority and then it can be easily expanded to reach "Glocal" dimension (depending on specific thematic fields and their attributes; some potential stakeholder examples are: European and Global Network of Geomining Parks or UNESCO World Heritage etc.).

\section{CONCLUSION}

The paper discusses the fabrics and the revival possibilities of mining heritage in Sardinia, aiming to explore local and global, "Glocal", government capacities. Pragmatically oriented with qualitative character, after theoretical and practical research, paper points out the necessity and urgency for changes of existing governing structure. 


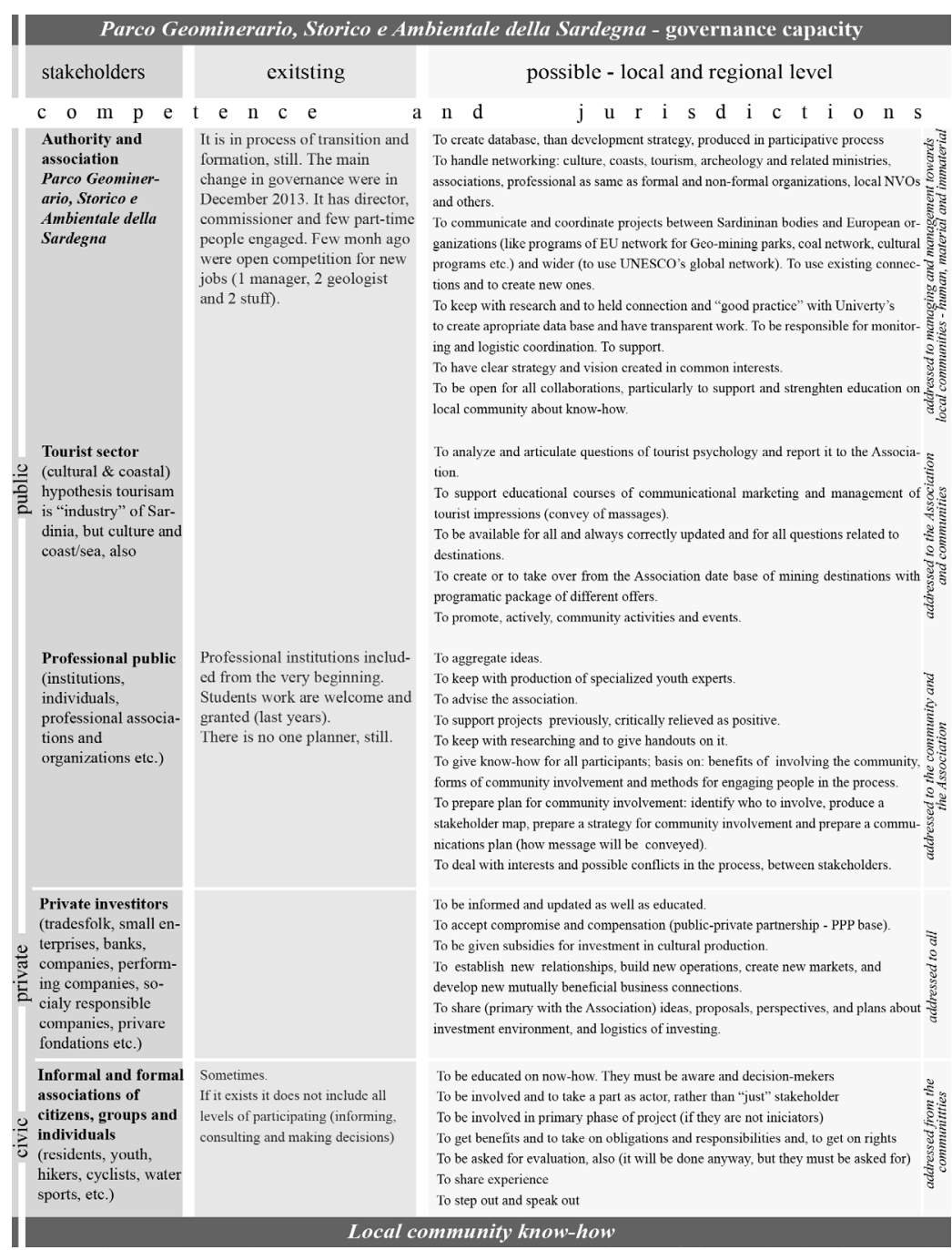

Figure 3. Parco Geominerario, Storico e Ambientale della Sardegna - governance capacity possibilities. 
Trends and potentials of Sardinian cities showed that new models of living and tourism fluctuations are shaking the limits of belonging, perceiving, evaluating and the subject we are projecting for. Driven by nature and culture, both oriented to long-lasting socio-cultural, economic and environmental sustainability, innovative government strategy should ensure dialogic relationship at local, territorial, Regional, European and global levels. This, "Glocal" (local and global), dimension is the main cultural opportunity for sustainable development system design. Governance capacity, to integrate local communities in participative, culture-led redevelopment process with sustainable tourism concept (balance of benefits and costs) is the main issues innovative strategies should meet. The questions to be tested (in accordance with EU strategies, too) address redevelopment, enhancement and satisfy, in accordance with local authorities and tour operators, tourism demand without compromising both the quality and natural heritage sites, which are important resources of these areas, both economic and social interests of the resident population at first.

More particularly, the paper argues about government capacities in the context of mining heritage in Sardinia. Characterized by more than 8 thousand years of mining history and ancient culture, after the failure in the 1960s, mining landscape was proclaimed by UNESCO an International heritage in 1997. Nowadays, heterogeneous Geo-mining Park, History and Ambient of Sardinia is symbolized as conceived, semi-perceived and pseudo-lived. Its revival process asks for representation of cultural identity, intensification of ordinary life that should be based upon proudness and built upon innovative local economies, recalling local community to be included in its own liveable-lovable place, participating in its governance process.

Public participation and collaboration are a contemporary necessity of a sustainable city. From the Sardinian 18 years practice, if the participation exists, it is not full - it does not include all levels of participating (informing, consulting and making decisions) or institutionalization. Secondly, planning (and planners) is missing. There is no implemented planning and planer's knowledge about know-how and communications techniques, meeting the interests of all stakeholders, of scientific and artistic fields (e.g. economic prosperity and faith, hope and love of habitats). There is also no institutionalization of participation, but it was not the issue of the paper. Turning into the initial revival steps of Sardinian mining landscapes (the place-based redevelopment process and cultural revitalization), according to existing capacities, the inter-government partnership could be a cultural planning model for long term sustainability, for acting "Glocal". The paper presented diagram that explains axes of partnership 
and, finally, the one possible organisational model according to the existing capacity with stakeholders and its categories, competence and jurisdictions and goals they can contribute to.

Likewise, huge potentials of Geo-mining Park, History and Ambient of Sardinia to revive its local and global, "Glocal", character exist, but the new governance model is missing. Leading to culture-led regeneration, aimed to have liveablelovable places (which main role is representation based on local economy), existing top-down strategic key must work parallely with bottom-up strategic key, starting with giving know-how to local communities. ed. Sara Marini, (Venezia: Università Iuav di Venezia, 2008), 255-260. 
Darko Radović, “In the Search of Urban Quality,” in In the Search of Urban Quality, eds.Darko Radović and Davisi Boontharm (Tokyo: International Keio Institute - IKI: Japan, 2014), 11-24. William H. Ittelson, An Introduction to Environmental Psychology. (American publishing company: Holt McDougal 1974).

Chris Tilley Part I: Landscape - Theoretical and Contemporary Perspectives. In Tilley, C. (Ed.) A Phenomenology of Landscape Places, Paths and Monuments (UK Oxford \& USA Providence: Berg Publishers, 1994), 7-67.

Henri Lefebvre, The production of space, transl. from French by Donald Nicholson-Smith (Malden - US, Oxford -UK, Carlton, Victoria - Australia: Blackwell publishing) 1991.

Kengo Kuma, "Symposium: Measuring the Non-Measurable - Intensities in ten Cities," (From the notes by Zoran Đukanović. Lecture held at Keio University, Tokyo, Japan, November 7, 2011). Available at: http://ec.europa.eu/europe2020/index en.htm

Patsy Healey, Collaborative Planning: Shaping Places in Fragmented Societies (Canada: UBC Press, 1997).

John Forester, "Planning in the Face of Conflict: Negotiation and Mediation Strategies in local Land Use Regulation," Journals of American Planning Association 53 (1987): 303-314. Ann Markusen and Anne Gadwa, "Components of Successful Placemaking Initia tives," in Creative Placemaking eds. Ann Markusen and Anne Gadwa (Washington DC: National Endowment for the arts - Markusen Economic Research Services and Metris Arts Consulting, 2010), 18-23. of Belgrade in collaboration with University of Sassari, 2014; available at official site of Public art \& Public space - PaPs: http://www.publicart-publicspace.org/projects/annual-projects/012paps-2014-revival-of-mining-landscape-in-sardinia

Creative cultures, Leading the good life: Guidance on integrating cultural and community strategies. London DCMS: Creative tourism New Zealand, 2004; available at: http://www. creativetourism.co.nz.

Plaisant, Alessandro. Costruire paesaggi. Visioni collettive e partecipate. Sassari: Facolta di Architettura, Dipartamento di Architettura e Pianificazione, Universita di Sassari, 2010.

Peghin, Giorgio and Antonello, Sanna, Modern Urban Heritage. Experiences and Reflections for the Twentieth Century City. (London: Um berto Allemandi \& Co, 2012.

Riegl, Alois. "The Modern Cult of Monuments: Its Essence and Its Development." In Historical and Philosophical Issues on the Conservation of Cultural Heritage, eds.Stanley Price, Kirby Talley, and Melucco Vaccaro, 69-83. Los Angeles: Getty Conservation Institute, 1996.

Sella, Quintino. Sulle condizioni dell'industria mineraria nell'isola di Sardegn. Nuoro: Ilisso edizioni., 1950. 


\section{ULOGA LOKALNE UPRAVE U PROCESU REGENERACIJE BRAUNFILD LOKACIJA: EVROPSKA PLANERSKA PRAKSA \\ Ana Perić}

Pošto mnogobrojni učesnici sa različitim interesima u procesu braunfild regeneracije povećavaju složenost samog procesa, zanimljivo je posmatrati prirodu njihove saradnje. Fokus ovog rada je na ulozi lokalnih vlasti kao jednom od ključnih stejkholdera odgovornih za uspeh braunfild regeneracije. Položaj kao i instrumenti koje koristi lokalna uprava u datom procesu mogu se rasvetliti kroz posmatranje organizacije planskog procesa, pregovaračkih i procedura donošenja odluka, kao i načina rešavanja konflikata. Empirijski istraživački okvir ovog rada čine dve evropske studije slučaja braunfild regeneracije: nekadašnja fabrika kablova i žica u Beču i bivše romsko naselje u Budimpešti. Rad daje uvid u mogućnosti za redefinisanje planske kulture kroz inovativne i proaktivne planske pristupe braunfild regeneraciji.

KLJUČNE REČI: REGENERACIJA BRAUNFILDA, LOKALNA UPRAVA, KOLABORACIJA, BEČ, BUDIMPEŠTA

\section{LOKALNA UPRAVA, DRUŠTVENO-PROSTORNI RAZVOJ I SEGREGACIJA U POST-TRANZICIONOJ MAĐARSKOJ \\ Nora Teller}

Svedoci smo ponovnog skaliranja koncepta upravljanja u Zapadnoj Evropi poslednjih 25 godina. U ovom radu se daje pregled literature o pojavama koje se odnose na promene u upravljanju urbanim planiranjem izazvane uticajem neoliberalnog režima, i naglašavaju se paralelna pitanja u kontekstu post-tranzicione Mađarske. Izazovi lokalne samouprave su diskutovani kroz prizmu mehanizama koji su podstakli segregaciju u mađarskom urbanom kontekstu. U radu se zaključuje da je glokalizacija, podstaknuta nedavno razvijenim politikama rešavanja problema urbane nejednakosti i segregacije finansiranim iz fondova EU, glavni ishod decentralizacije javne uprave u Mađarskoj. Međutim, jednim delom neki od pokušaja urbane rehabilitacije su zasnovani na 'disekonomijama sukoba', što ukazuje da rezultati mogu postati neodrživi u budućnosti.

\section{KAPACITET “GLOKALNOG” UPRAVLJANJA: RUDARSKO NASLEĐE SARDINIJE}

\section{Nađa Beretić, Arnaldo Bibo Cecchini, Zoran Đukanović, Alessandro Plaisant}

Rad se bavi istraživanjem kapaciteta upravljanja rudnim industrijskim nasleđem Sardinije. Rudarska kultura Sardinije datira iz perioda od pre 8 hiljada godina, gde je oduvek predstavljala industrijski razvojni motor regiona, ugašena je '60-ih godina prošlog veka, a kasnije, 1997. godine, proglašena od strane UNESCO-a za nasleđe od izuzetnog značaja. Danas, ovi predeli se odlikuju izrazitom depopulacijom, i nedovoljnim kapacitetima upravljanja i rukovođenja; pejzaži izuzetne lepote imaju karakter osmišljenih, ali polu-doživljenih i pseudo-živih mesta. Istraživanje je pragmatične orijentacije, sa kvalititativnim karakterom; orijentisano da utvrdi šta i kako treba raditi u odnosu na željenu budućnost. Ono je multidisciplinarnog pristupa i uvek podrazumeva istraživanje u određenom društvenom, istorijskom, ekonomskom i političkom kontekstu.

Ispitivanje trendova i urbanih potencijala sardinijske teritorije rađeno je u komparaciji sa savremenom evropskom strategijom. Istraživanje govori o "zajedničkom kulturnom iskustvu" kao dugoročnoj komponenti održivosti, koja počiva, zasnovana je i pokreće se, na nivou lokalne zajednice.

Glavno pitanje rada razmatra "Glokalnu", lokalnu i globalnu, sposobnost upravljanja pomoću "ose partnerstva” (lokalni nivo - Parco Geominerario Storico e Ambientale - evropska i globalna mreža geoparkova - UNESKO), kao prve komponente kreativnog partnerstva, koja vodi ka integrisanju lokalne zajednice u participativni, kulturni, proces ponovnog razvoja, u kontekstu sardinijskog rudnog nasleđa kao održivog dizajna ovog sistema. 